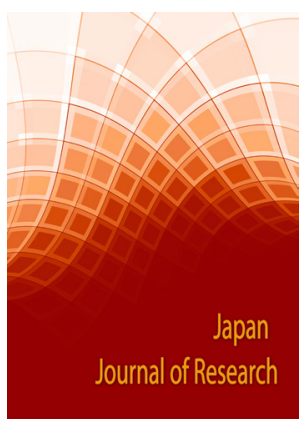

Correspondence

Elias Randjbaran

Department of Aerospace Engineering, Faculty of Engineering 43400 UPM, Serdang, Selangor, Malaysia

E-mail: Elias@gmx.co.uk

- Received Date: 03 Aug 2019;

- Accepted Date: 19 Sep 2019;

- Publication Date: 24 Sep 2019.

\section{Copyright}

(C) 2019 Science Excel. This is an openaccess article distributed under the terms of the Creative Commons Attribution 4.0 International license.

\title{
Literature review on the relation between tensile strength and flexural strength in isotropic material
}

\author{
Elias Randjbaran 1", Dayang Laila Abang Haji Abdul Majid', Mohamed Thariq Bin \\ Hameed Sultan', Norkhairunnisa Mazlan' and Rizal Zahari2 \\ 'Department of Aerospace Engineering, Faculty of Engineering 43400 UPM, Serdang, Selangor, Malaysia \\ ${ }^{2}$ Systems Engineering Department, Military Technological College, Muscat, Sultanate of Oman
}

\begin{abstract}
The relations between the relation between tensile strength and flexural strength in isotropic material parameters are in isotropic materials to review the relation between tensile strength and flexural strength in isotropic materials and relation between tensile modulus and flexural modulus in isotropic materials. Moreover, the reasons of flexural strength higher than tensile strength in isotropic material are studied. For example, possibilities such as voids and micro aggregations can have more effects on tensile strength than flexural strength are investigated. Within the realm of science, mechanical strength might increase the consequences of composite materials. Moreover, fundamental aspects of tensile strength could relate to this reality that the demerits of isotropic materials and relation to tensile modulus and flexural modulus in isotropic materials pertain. As a tangible example, some scientific research undertaken by the prestigious scholars have asserted that the reasons of flexural strength higher than tensile strength correlated negatively with isotropic material. Hence, it is correct to presume the preconceived notion of isotropic material. Consequently, from an academic stand point, possibilities such as voids and micro aggregations can provide the scientific with some noticeable effects, which related in the fact that merits of effects on tensile strength as well as flexural strength, are inextricably bound up. Nevertheless, according to the literature an academic, the beneficial ramification of both tensile strength and flexural strength in isotropic material parameters apparently can be seen. To conclude, while there are several compelling arguments on both sides. Notwithstanding it can be shown that benefits of voids and micro aggregations far outweigh of its drawbacks. Not only do the advantages prove the significance of flexural strength, but also pinpoint tensile strength implications.
\end{abstract}

\section{Introduction}

The materials had ruled the market as far as their flexibility for item's applications When the introduction of polymer materials science in the 1930s. Stress is defined as the force per unit area. Thus, the formula for calculating stress is [1-11]:

$$
\sigma=\mathrm{F} / \mathrm{A}
$$

Where $\sigma$ identifies stress, $\mathrm{F}$ is load and $\mathrm{A}$ is the cross sectional area. The most usual use units for stress are the SI units, or Pascal's (or N/m2), although other units such as psi (pounds per square inch) are sometimes used. Forces can be applied in different directions like Tensile or stretching, Compressive or squashing/crushing, Shear or tearing/cutting, and Torsional or twisting [11-23].

This gives rise to numerous corresponding types of stresses and hence measure/quoted strengths. Since data sheets often quote values for strength (as compressive strength), these values are purely uniaxial, and it should be noted that in real life several different stresses can be acting [22-41].

The tensile strength is defined as the maximum tensile load a body can withstand before failure divided by its cross sectional area. This property is also sometimes referred to Ultimate Tensile Stress or UTS [39-49]. Figure 1 illustrates Ultimate tensile strength, often shortened to tensile strength, ultimate strength, or Ftu within equations, is the capacity of a material or structure to withstand loads tending to elongate, as opposed to compressive strength, which withstands loads tending to reduce size.

Typically, ceramics perform poorly in tension, while metals are quite good. Fibres such as glass, Kevlar and carbon fibre are often added polymeric materials in the direction of the tensile force to reinforce or improve their tensile strength [48-54].

Compressive strength is defined as the maximum compressive load a body can bear prior to failure, divided by its cross sectional area [50-59]. Figure 2 shows Compressive strength or compression strength is the capacity of a material or structure to withstand loads tending to reduce size, as opposed to tensile strength, which withstands loads tending to elongate. In other words, compressive strength resists compression, whereas tensile strength resists tension. 
Ceramics typically have good tensile strengths and are used under compression e.g. concrete.

Shear strength is the maximum shear load a body can withstand before failure occurs divided by its cross sectional area [50-51]. Figure 3 illustrates shear strength is the strength of a material or component against the type of yield or structural failure when the material or component fails in shear. A shear load is a force that tends to produce a sliding failure on a material along a plane that is parallel to the direction of the force.

This property is relevant to adhesives and fasteners as well as in operations like the guillotining of sheet metals [51-56].

Torsional strength is the maximum amount of torsional stress a body can withstand before it fails, divided by its cross sectional area [58]. Figure 4 shows the ability of a material to withstand a twisting load. It is the ultimate strength of a material subjected to torsional loading, and is the maximum torsional stress that a material sustains before rupture. Alternate terms are modulus of rupture and shear strength.

This property is relevant for components such as shafts.

Yield strength is defined as the stress at which a material changes from elastic deformation to plastic deformation. Once this point, known as the yield point is exceeded, the materials are no longer return to its original dimensions after the removal of the stress [58-68].

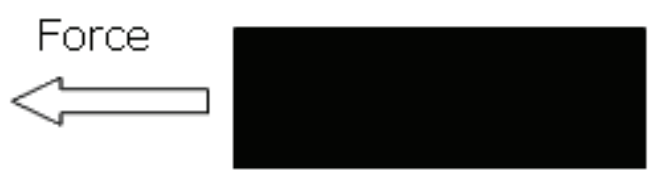

Force

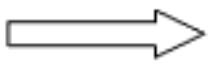

Figure 1. Tensile strengh

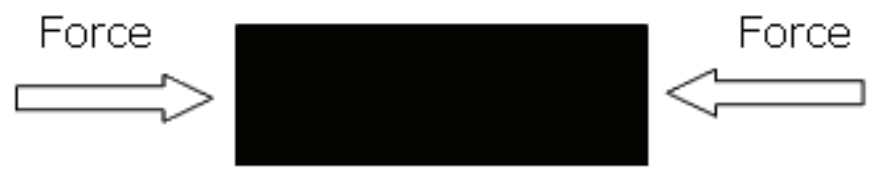

Figure 2. Compressive strength

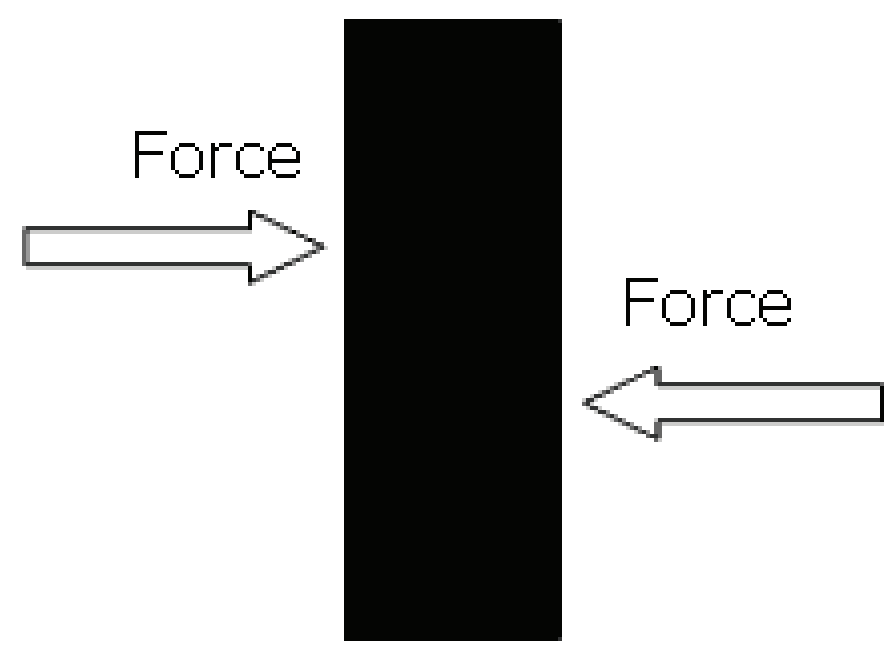

Figure 3. Shear strength

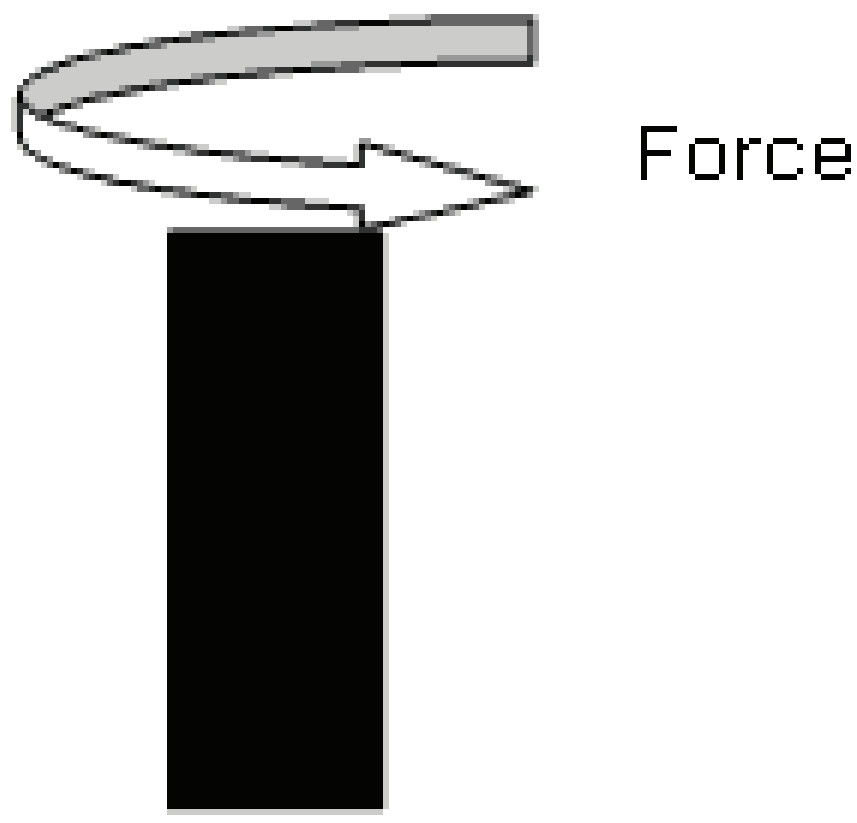

Figure 4. Torsional strength

\section{Results and Discussions}

Zero stress at neutral axis and compressive stresses in layers below the neutral axis since a material is tested in flexure that under bending; tensile stresses are produced on the top layers. In isotropic materials, when the material fails, the corresponding load is taken for calculation of flexural strength. As the isotropic material fails in tensile portion; the strength is nothing but its tensile strength. Hence when tested using tensile mode on a universal testing machine, also known as a universal tester, materials testing machine or materials test frame, is used to test the tensile strength and compressive strength of materials. An earlier name for a tensile testing machine is a tensometer [67-78].

Due to tensile strength and according to flexural loading test set-up, it can be called as flexural strength. Ideally both should be same. In fact for ceramic materials; tensile strength is obtained using 3-point bending set-up because tensile specimens for ceramic materials cannot be prepared. Only difference is; if some defect is present in the specimen; irrespective of its location; it affects tensile strength in the same manner because uniform tensile stresses are produced across the whole cross section. In bending situation however; defects will affect the strength differently depending upon their location. A defect nearer top or bottom surface will have significant effect as compared to the same type of defect located nearer or on the neutral axis. Hence the strength in two modes of testing may differ [75-89].

It has been given a universal formula for the relationship between tensile strength / modulus and flexural strength / modulus. This relationship depends on the type of the material and geometry of the sample. Theoretically, it should be the same [88-99].

The difference between the modules can be explained by influence of complex stress state of bent sample. If the material has different properties in tension / compression and to do so is not perfectly linear, the module computed using the linear theory is a certain "averaging" [98-101].

In case of differences in flexural strength and tensile strength can be affected by scale effects that can also be explained by statistical effects. The maximum stresses occur in a small area of the bending section, 
theoretically only on the edge. Since the entire cross section of the sample is under the maximum stresses during the tension test. Therefore, it is more likely to find a "weak point" from which the destruction starts. Correspondingly, smaller samples show greater strength than bigger ones [100-111].

A ratio between strength at a bend and strength at extension is difficult to receive the general. Theoretically, the problem can be solved having a big data file on strength at extension. Then it is possible to use the WeybulI-Gnedenko approach in case of the linear chart of extension and to consider large-scale effect that at extension more defects get to a zone of the maximum deformations [110-119].

As for the elasticity module, my opinion that it is identical at a bend and at extension and at compression. The methodical difference arises first because of deformations of shift at a bend, secondly because of a sample deformation in points of application of loading. For homogenous material or where modulus in tension and compression is same, both moduli should theoretically match [118-123].

\section{Conclusions}

This for example a thermoplastic material or the thermoplastic materials filled by particles. For a thermoplastic material, it can be found out the relationship. However, for the thermoplastic materials filled by particles, relationship could be found. If the particles have a high Young's modulus, tensile modulus of the filled thermoplastics can be higher than flexural modulus [115-119].

\section{References}

1. Cha J, Jin S, Shim JH, et al. Functionalization of carbon nanotubes for fabrication of CNT/epoxy nanocomposite. Materials \& Design. 2016; 95(50):1-8.

2. Ramanathan $M$, Shanov V, Kumta PN. Carbon Nanotube-Based Impedimetric Biosensors for Bone Marker Detection, Mitali Patil Department of Bioengineering, Swanson School of Engineering, University of Pittsburgh, Pittsburgh, Pennsylvania, USA, Advances in Materials Science for Environmental and Energy Technologies IV: Ceramic Transactions. 2015; 253:187.

3. Pradhan S, Pandey P, Mohanty S. Insight on the Chemistry of Epoxy and Its Curing for Coating Applications: A Detailed Investigation and Future Perspectives. Polymer-Plastics Technology and Engineering. 2016; 55(8): 862-877.

4. Hunnekens B, Peters F, Avramidis G, et al. Plasma treatment of wood-polymer composites: A comparison of three different discharge types and their effect on surface properties. Journal of Applied Polymer Science. 2016; 133: 18.

5. Bonduel D, Kchit N, Claes M. Use of carbon nanotubes in structural composites, Smart Intelligent Aircraft Structures (SARISTU), Springer International Publishing. 2016: 755-762

6. Chen Y, Zhang HB, Yang Y, et al. High-Performance Epoxy Nanocomposites Reinforced with Three-Dimensional Carbon Nanotube Sponge for Electromagnetic Interference Shielding, Advanced Functional Materials. 2016; 26(3): 447-455.

7. Islam MS, Deng Y, Tong L, et al. Grafting carbon nanotubes directly onto carbon fibers for superior mechanical stability: Towards next generation aerospace composites and energy storage applications. Carbon. 2016; 96: 701-710.

8. Tornabene F, Fantuzzi N, Bacciocchi $M$, et al. Effect of agglomeration on the natural frequencies of functionally graded carbon nanotube-reinforced laminated composite doubly-curved shells, Composites Part B: Engineering. 2016; 89:187218.

9. G'omez-del R'ı T, Salazar A, Pearson RA, et al. Fracture behaviour of epoxy nanocomposites modified with triblock copolymers and carbon nanotubes, Composites Part B: Engineering. 2016: 87: 343-349.

10. Fujigaya $T$, Saegusa $Y$, Momota $S$, et al. Interfacial engineering of epoxy/carbon nanotubes using reactive glue for effective reinforcement of the composite. Polymer Journal. 2016; 48(2):183-188.

11. Zhou HW, Mishnaevsky L, Yi HY, et al. Carbon fiber/carbon nanotube reinforced hierarchical composites: Effect of CNT distribution on shearing strength, Composites Part B: Engineering. 2016; 88:201-211

12. Randjbaran $E$, Zahari $R$, Abdul Jalil NA, et al. Hybrid composite laminates reinforced with kevlar/carbon/glass woven fabrics for ballistic impact testing. The Scientific World Journal. 2014

13. Randjbaran $\mathrm{E}$, Zahari $\mathrm{R}$, Majid $\mathrm{DL}$, et al. The effects of stacking sequence layers of six layers composite materials in ballistic energy absorption, International Journal of Material Science Innovations. 2013; 1(6): 293-305.
14. Randjbaran E, Zahari R, Majid DL, et al. The effects of stacking sequence layers of hybrid composite materials in energy absorption under the high velocity ballistic impact conditions: an experimental investigation. Journal of Material Sciences \& Engineering. 2013.

15. Randjbaran E, Zahari R, Majid DL, et al. Effects of Stacking Sequence on Compression Response Testing of Carbon Fibre and Hybrids: Fibrous-Glass/ Carbon/Kevlar/Epoxy Composite Plates, MATRIX Academic International Online Journal of Engineering and Technology. 2013; 2(1): 13-17.

16. Randjbaran E, Zahari R, Majid DL, et al. Experimental Study of the Influence of Stacking Order of the Fibrous Layers on Laminated Hybrid Composite Plates Subjected to Compression Loading. Journal of Science and Engineering. 2014; 4(1):1-8.

17. Randjbaran $\mathrm{E}$, Zahari R, Vaghei R et al. A Review Paper on Comparison of Numerical Techniques for Finding Approximate Solutions to Boundary Value Problems on Post-Buckling in Functionally Graded Materials. Trends Journal of Sciences Research. 2015; 1(1):1-6.

18. Randjbaran E, Zahari R, Vaghei R. Scanning Electron Microscopy Interpretation In Carbon Nanotubes Composite Materials After Postbuckling - Review Paper. MATRIX Academic International Online Journal of Engineering and Technology. 2014;2(2):1-6.

19. Randjbaran E, Zahari R, Vaghei R. Computing Simulation of Postbuckling in Functionally Graded Materials - A Review. Indonesian Journal of Electrical Engineering and Computer Science. 2014;12(12):8344-8348.

20. Randjbaran E, Zahari R, Majid DL, et al. Effects of Carbon Nanotube on Mechanical Properties of Composite plates -A Review Paper. MATRIX Academic International Online Journal of Engineering and Technology. 2015; 3(2):1-8.

21. Reddy PR, Reddy TS, Srikanth I, et al. Effect of viscoelastic behaviour of glass laminates on their energy absorption subjected to high velocity impact. Materials \& Design. 2016; 98:272-279.

22. Saba N, Paridah MT, Abdan K et al. Dynamic mechanical properties of oil palm nano filler/kenaf/epoxy hybrid nanocomposites, Construction and Building Materials. 2016;124:133-138.

23. Ostovan F, Matori KA, Toozandehjani M, et al. Effects of CNTs content and milling time on mechanical behavior of MWCNT-reinforced aluminum nanocomposites, Materials Chemistry and Physics. 2015; 166:160-166.

24. Shabaneh A, Girei S, Arasu P, et al. Dynamic response of tapered optical multimode fiber coated with carbon nanotubes for ethanol sensing application. Sensors. 2015;15(5): 10452-10464.

25. Ramli NI, Rashid SA, Sulaiman Y, et al. Physicochemical and electrochemical properties of carbon nanotube/graphite nanofiber hybrid nanocomposites for supercapacitor, Journal of Power Sources. 2016; 328: 195-202.

26. Ghaemi F, Yunus R, Salleh MA, et al. Effects of the surface modification of carbon fiber by growing different types of carbon nanomaterials on the mechanical and thermal properties of polypropylene. RSC Advances. 2015; 5(36): 28822-28831.

27. Shojaei TR, Salleh MA, Sijam K, et al. Fluorometric immunoassay for detecting the plant virus Citrus tristeza using carbon nanoparticles acting as quenchers and antibodies labeled with CdTe quantum dots. Microchimica Acta. 2016; 1-1.

28. Lomicka CW, Thomas JA, LaBarre ED, et al. Improving ballistic fiber strength insights from experiment and simulation. Dynamic Behavior of Materials. 2014; 1:187-193.

29. Randjbaran E, Zahari R, Majid DL, et al. Effects of Sloped Armour in Ballistic Impact Resistance - A Review Paper. MATRIX Academic International Online Journal of Engineering and Technology. 2016; 4(2): 19-26.

30. Shang Y, Hua C, Xu W, et al. Meter-Long Spiral Carbon Nanotube Fibers Show Ultrauniformity and Flexibility. Nano letters. 2016;16(3): 1768-1775.

31. Wu X, Morimoto T, Mukai K, et al. Relationship between Mechanical and Electrical Properties of Continuous Polymer-Free Carbon Nanotube Fibers by Wet-Spinning Method and Nanotube-Length Estimated by Farlnfrared Spectroscopy. J Phys Chem C. 2016;120(36) 20419-20427.

32. Liu P, Fan Z, Mikhalchan A, et al. Continuous Carbon Nanotube-Based Fibers and Films for Applications Requiring Enhanced Heat Dissipation. ACS Applied Materials \&Interfaces. 2016; 8(27):17461-17471.

33. $\mathrm{Xu} \mathrm{W}$, Chen $\mathrm{Y}$, Zhan $\mathrm{H}$, et al. High-Strength Carbon Nanotube Film from Improving Alignment and Densification. Nano letters. 2016; 16(2): 946-952.

34. Zare M, Rayegan-Shirazi A, Rezaei S, et al. Effects of Polychlorinated biphenyls compounds on the number of bacteria in the rhizosphere of sorghum and Onobrychis sativa. Advances in Bioresearch. 2016; 7:3.

35. Elias Randjbaran, Rizal Zahari, Dayang L Majid, et al. Mechanical Properties of Disconnected Multiwalled Carbon Nanotubes and Carbon Nanotube Composites - A Review Paper. International Journal of Research - Granthaalayah. 2018; 6(6): 212-225.

36. Davaa E, Safari M, Randjbaran E, et al. The Factors That Influence Customer Satisfaction Level in the Mongolian Banking Industry. Journal of Insurance and Financial Management. 2016; 1:3. 
37. O'Connor I, Hayden $\mathrm{H}$, Coleman JN, et al. High-Strength, High-Toughness Composite Fibers by Swelling Kevlar in Nanotube Suspensions. Small. 2009; 5(4):466-469.

38. Govarthanam KK, Anand SC, Rajendran S. 7 Technical textiles for knife and slash resistance, Handbook of Technical Textiles: Technical Textile Applications. 2016; 2: 193.

39. Dwivedi AK, Dalzell MW, Fossey SA, et al. Low velocity ballistic behavior of continuous filament knit aramid. International Journal of Impact Engineering. 2016; 96: 23-34.

40. Yang $D$, Chen X. Multi-layer pattern creation for seamless front female body armor panel using angle-interlock woven fabrics.Textile Research Journal. 2016; 0040517516631315 .

41. Lomicka CW, Thomas JA, LaBarre ED, et al. Improving ballistic fiber strength: insights from experiment and simulation. Dynamic Behavior of Materials. 2014; 1: 187-193.

42. Sockalingam S, Chowdhury SC, Gillespie JW, et al. Recent advances in modeling and experiments of Kevlar ballistic fibrils, fibers, yarns and flexible woven textile fabrics-a review. Textile Research Journal. 2016; 004051751664603.

43. O'Connor I, Hayden H, Coleman JN, et al. High-Strength, High-Toughness Composite Fibers by Swelling Kevlar in Nanotube Suspensions. Small. 2009; 5(4)466-469.

44. Zheng J, Duan $\mathrm{X}$, Lin $\mathrm{H}$, et al. Silver nanoparticles confined in carbon nanotubes: on the understanding of the confinement effect and promotional catalysis for the selective hydrogenation of dimethyl oxalate. Nanoscale. 2016; 8(11):5959-5967.

45. Haft M, Gronke M, Gellesch M, et al. Tailored nanoparticles and wires of Sn, Ge and $\mathrm{Pb}$ inside carbon nanotubes. Carbon. 2016; 101:352-360.

46. Gunko VM, Do DD. Characterisation of pore structure of carbon adsorbents using regularisation procedure. Colloids and Surfaces A: Physicochemical and Engineering Aspects. 2001; 193( 1):71-83.

47. Gunko VM, Mikhalovsky SV. Evaluation of slitlike porosity of carbon adsorbents. Carbon. 204; 42(4): 843-849.

48. Jiang LY, Huang $\mathrm{Y}$, Jiang $\mathrm{H}$, et al. A cohesive law for carbon nanotube/polymer interfaces based on the van der Waals force. Journal of the Mechanics and Physics of Solids. 2006; 54(11): 2436-2452.

49. Wong $M$, Paramsothy $M, X u X J$, et al. Physical interactions at carbon nanotubepolymer interface. Polymer. 2003; 44(25): 7757-7764.

50. Liao K, Li S. Interfacial characteristics of a carbon nanotube-polystyrene composite system. Applied Physics Letters. 2001; 79(25):4225-4227.

51. Veedu VP, Cao A, Li X, et al. Multifunctional composites using reinforced laminae with carbon-nanotube forests, Nature materials. 2006; 5(6):457-462.

52. Wang $Y$, Colas G, Filleter T. Improvements in the mechanical properties of carbon nanotube fibers through graphene oxide interlocking. Carbon. 2016; 98: 291-299.

53. Koizumi R, Hart AH, Brunetto $G$, et al. Mechano-chemical stabilization of threedimensional carbon nanotube aggregates. Carbon. 2016; 110: 27-33.

54. Chowdhury SC, Okabe T. Computer simulation of carbon nanotube pullout from polymer by the molecular dynamics method. Composites Part A: Applied Science and Manufacturing. 2007; 38(3):747-754.

55. Li Y, Liu Y, Peng $X$, et al. Pull-out simulations on interfacial properties of carbon nanotube-reinforced polymer nanocomposites. Computational Materials Science. 2011; 50(6): 1854-1860.

56. Wagner HD, Vaia RA. Nanocomposites: issues at the interface. Materials Today. 2004; 7(11):38-42.

57. Wagner HD, Ajayan PM, Schulte K. Nanocomposite toughness from a pull-out mechanism. Composites Science and Technology. 2013; 83:27-31.

58. Esawi AM, Morsi K, Sayed A, et al. Effect of carbon nanotube (CNT) content on the mechanical properties of CNT-reinforced aluminium composites. Composites Science and Technology. 2010; 70(16): 2237-2241.

59. He XQ, Kitipornchai S, Liew KM. Buckling analysis of multi-walled carbon nanotubes: a continuum model accounting for van der Waals interaction. Journal of the Mechanics and Physics of Solids. 2005; 53(2):303-26.

60. Jiang $L Y$, Huang $Y$, Jiang $H$, et al. A cohesive law for carbon nanotube/polymer interfaces based on the van der Waals force. Journal of the Mechanics and Physics of Solids. 2006; 54(11):2436-2452.

61. Tan $H$, Jiang $L Y$, Huang $Y$, et al. The effect of van der Waals-based interface cohesive law on carbon nanotube-reinforced composite materials. Composites Science and Technology. 2007; 67(14):2941-2946.

62. Liu X, Yang QS, He XQ et al. Cohesive laws for van der Waals interactions of super carbon nanotube/polymer composites. Mechanics Research Communications. 2016; 72:33-40

63. Nagataki A, Takei $K$, Arie $T$ et al. Carbon nanotube mechanical resonator in potential well induced by van der Waals interaction with grapheme. Applied Physics Express. 2015; 8(8): 085101.

64. Zhang X, Zhou WX, Chen XK, et al. Significant decrease in thermal conductivity of multi-walled carbon nanotube induced by interwall van der Waals interactions. Physics Letters A. 2016; 380(21): 1861-1864.

65. Chernozatonskii LA, Artyukh AA, Demin VA et al. Bucky-corn: van der Waals composite of carbon nanotube coated by fullerenes. Molecular Physics. 2016; 114(9)92-101.

66. Perebeinos $\mathrm{V}$, Tersoff J. Wetting transition for carbon nanotube arrays under metal contacts. Physical review letters. 2015; 114(8): 085501.

67. Tornabene F, Fantuzzi N, Bacciocchi M, et al. Effect of agglomeration on the natural frequencies of functionally graded carbon nanotube-reinforced laminated composite doubly-curved shells. Composites Part B: Engineering. 2016; 89: $187-$ 218.

68. Kumar AA, Sundaram R. Cure cycle optimization for the resin infusion technique using carbon nanotube additives. Carbon. 2016; 96: 1043-1052.

69. Kamarian S, Salim M, Dimitri R, et al. Free vibration analysis of conical shells reinforced with agglomerated Carbon Nanotubes, International Journal of Mechanical Sciences. 2016; 108:157-165.

70. Rathore DK, Singh BP, Mohanty SC, et al. Temperature dependent reinforcement efficiency of carbon nanotube in polymer composite. Composites Communications. 2016; 1:29-32.

71. Bautista-Quijano JR, Potschke $P$, Brunig $H$ et al. Strain sensing, electrical and mechanical properties of polycarbonate/multiwall carbon nanotube monofilament fibers fabricated by melt spinning. Polymer. 2016; 82: 181-189.

72. Herceg TM, Abidin MS, Greenhalgh ES, et al. Thermosetting hierarchical composites with high carbon nanotube loadings: Enroute to high performance. Composites Science and Technology. 2016; 127:134-41.

73. Wang J, BahkYK, Chen SC, et al. Characteristics of airborne fractal-like agglomerates of carbon nanotubes. Carbon. 2015; 93:441-450.

74. Moghadam AD, Omrani E, Menezes PL, et al. Mechanical and tribological properties of self-lubricating metal matrix nanocomposites reinforced by carbon nanotubes (CNTs) and graphene-a review. Composites Part B: Engineering. 2015; 77: 402-420.

75. Chen SJ, Qiu CY, Korayem AH, et al. Agglomeration process of surfactant-dispersed carbon nanotubes in unstable dispersion: A two-stage agglomeration model and experimental evidence. Powder Technology. 2016; 301:412-420.

76. Romanov VS, Lomov SV, Verpoest I, et al. Stress magnification due to carbon nanotube agglomeration in composites. Composite Structures. 2015; 133: 246256.

77. Balasubramanian K, Burghard M. Chemically functionalized carbon nanotubes Small. 2005; 1(2): 180-192.

78. Wong SS, Joselevich E, Woolley AT, et al. Covalently functionalized nanotubes as nanometre-sized probes in chemistry and biology. Nature. 1998; 394: 6688.

79. Banerjee S, Hemraj-Benny T, Wong SS. Covalent surface chemistry of single-walled carbon nanotubes. Advanced Materials. 2005; 17(1):17-29.

80. Bianco A, Kostarelos K, Prato M. Applications of carbon nanotubes in drug delivery, Current opinion in chemical biology. 2005; 9(6):674-679.

81. Spitalsky Z, Tasis D, Papagelis K et al. Carbon nanotube-polymer composites: chemistry, processing, mechanical and electrical properties. Progress in polymer science. 2010; 35(3): 357-401.

82. Salvetat JP, Bonard JM, Thomson NH, et al. Mechanical properties of carbon nanotubes. Applied Physics A. 1999; 69(3): 255-260.

83. Wei BQ, Vajtai R, Ajayan PM. Reliability and current carrying capacity of carbon nanotubes. Applied Physics Letters. 2001; 79(8): 1172.

84. Li QW, Li Y, Zhang XF, et al. Structure-dependent electrical properties of carbon nanotube fibers. Advanced Materials. 2007; 19(20): 3358-3363.

85. Dumitrica T, Landis CM, Yakobson BI. Curvature-induced polarization in carbon nanoshells, Chemical physics letters. 2002; 360(1): 182-188.

86. Zhang HW, Wang JB, Guo X. Predicting the elastic properties of single-walled carbon nanotubes. Journal of the Mechanics and Physics of Solids. 2005; 53(9):1929-1950.

87. Banhart F. Interactions between metals and carbon nanotubes: at the interface between old and new materials, Nanoscale. 2019; 1(2) 201-213.

88. Jakubinek MB, Ashrafi B, Zhang Y, et al. Single-walled carbon nanotube-epoxy composites for structural and conductive aerospace adhesives. Composites Part B: Engineering. 2015; 69:87-93.

89. Papadopoulos A, Gkikas G, Paipetis AS, et al. Effect of CNTs addition on the erosive wear response of epoxy resin and carbon fibre composites. Composites Part A Applied Science and Manufacturing. 2016; 84:299-307.

90. Fujigaya T, Saegusa Y, Momota S, et al. Interfacial engineering of epoxy/carbon nanotubes using reactive glue for effective reinforcement of the composite. Polymer Journal. 2016; 48(2): 183-188.

91. Sun Y, Lu J, Ai C, et al. Multilevel resistive switching and nonvolatile memory effects in epoxy methacrylate resin and carbon nanotube composite films. Organic Electronics. 2016; 32: 7-14. 
92. Ling Y, Li W, Wang B, et al. Epoxy resin reinforced with nanothin polydopaminecoated carbon nanotubes: a study of the interfacial polymer layer thickness. RSC Advances. 2016; 6(37):31037-31045.

93. Mei $\mathrm{H}$, Zhang $\mathrm{S}$, Chen $\mathrm{H}$, et al. Interfacial modification and enhancement of toughening mechanisms in epoxy composites with CNTs grafted on carbon fibers, Composites Science and Technology. 2016; 134: 89-95.

94. Wu J, Chen J, Zhao $Y$, et al. Effect of electrophoretic condition on the electromagnetic interference shielding performance of reduced graphene oxidecarbon fiber/epoxy resin composites. Composites Part B: Engineering. 2016; 105:167-175.

95. Elias Randjbaran. Literature Review of Investigating Mechanical Properties of Disconnected Multiwalled Carbon Nanotubes into Composite. SF J Material Res Let 2018; 2:2. http://www.scifedpublishers.com/open-access/literature-reviewof-investigating-mechanical-properties-of-disconnectedrnmultiwalled-carbonnanotubes-into-composite.pdf.

96. Schlagenhauf L, Buerki-Thurnherr T, Kuo YY, et al. Carbon Nanotubes Released from an Epoxy-Based Nanocomposite: Quantification and Particle Toxicity. Environmental Science \& Technology. 2015; 49(17):10616-10623.

97. Rafique I, Kausar A, Anwar Z, et al. Exploration of Epoxy Resins, Hardening Systems, and Epoxy/Carbon Nanotube Composite Designed for High Performance Materials: A Review. Polymer-Plastics Technology and Engineering. 2016; 55(3): 312-333.

98. Schlagenhauf L, Kuo YY, Bahk YK, et al. Decomposition and particle release of a carbon nanotube/epoxy nanocomposite at elevated temperatures. Journal of Nanoparticle Research. 2015; 17(11): 1-11.

99. Gong LX, Zhao L, Tang LC, et al. Balanced electrical, thermal and mechanical properties of epoxy composites filled with chemically reduced graphene oxide and rubber nanoparticles. Composites Science and Technology. 2015; 121: $104-$ 114.

100. Pathak AK, Borah M, Gupta A, et al. Improved mechanical properties of carbon fiber/graphene oxide-epoxy hybrid composites. Composites Science and Technology. 2016;135:28-38.

101. Wang J, Zhao Y, Ma FX, et al. Synthesis of a hydrophilic poly-L-lysine/graphene hybrid through multiple noncovalent interactions for biosensors. Journal of Materials Chemistry B. 2013; 1(10):1406-1413.

102. Tallury SS, Pasquinelli MA. Molecular dynamics simulations of polymers with stiff backbones interacting with single-walled carbon nanotubes. The Journal of Physical Chemistry B. 2010; 114(2): 9349-9355.

103. Pan B, Xing B. Adsorption mechanisms of organic chemicals on carbon nanotubes. Environmental Science \& Technology. 2018; 42(24): 9005-9013.

104. Xu Z, Wei C, Gong Y, et al. Efficient dispersion of carbon nanotube by synergistic effects of sisal cellulose nano-fiber and graphene oxide. Composite Interfaces. 2016; $1-5$.

105. Wang $Y, X u Z$ Z. Interaction mechanism of doxorubicin and SWCNT: protonation and diameter effects on drug loading and releasing. RSC advances. 2016; 6(6): 314-322.

106. Hua $Z$, Qin $Q$, Bai $X$, et al. An electrochemical biosensing platform based on 1-formylpyrene functionalized reduced graphene oxide for sensitive determination of phenol. RSC Advances. 2016; 6(30): 25427-25434.

107. Wang $Y$, Ren $P, G u X$, et al. Probing the mechanism of benzaldehyde reduction to chiral hydrobenzoin on the CNT surface under near-UV light irradiation. Green Chemistry. 2016; 18(6) 1482-1487.

108. L'opez-Lorente Al, Valc'arcel M. The third way in analytical nanoscience and nanotechnology: Involvement of nanotools and nanoanalytes in the same analytical process. TrAC Trends in Analytical Chemistry. 2016; 75: 1-9.

109. Kazemi-Beydokhti A, Heris SZ, Jaafari MR. Investigation of different methods for cisplatin loading using single-walled carbon nanotube. Chemical Engineering Research and Design. 2016; 112: 56-63.

110. Hajibadi $\mathrm{H}$, Nowroozi A. Study on the interaction of metallocene catalysts with the surface of carbon nanotubes and its influence on the catalytic properties. Investigation of possible complex structures and the influence on structural and electronic properties. Journal of Organometallic Chemistry. 2016.

111. Li J, Lee EC. Functionalized multi-wall carbon nanotubes as an efficient additive for electrochemical DNA sensor. Sensors and Actuators B: Chemical. 2017; 239:652659

112. Bal S, Samal SS. Carbon nanotube reinforced polymer composites -a state of the art, Bulletin of Materials Science. 2017;30 (4):379-86.

113. Chen $Y$, Zhang $H B$, Yang $Y$, et al. High-Performance Epoxy Nanocomposites Reinforced with Three-Dimensional Carbon Nanotube Sponge for Electromagnetic Interference Shielding. Advanced Functional Materials. 2016;26(3): 447-455.

114. Fujigaya T, Saegusa $Y$, Momota $S$, et al. Interfacial engineering of epoxy/carbon nanotubes using reactive glue for effective reinforcement of the composite. Polymer Journal. 2016;48(2):183-188.

115. Bakhtiar NS, Akil HM, Zakaria MR, et al. New generation of hybrid filler for producing epoxy nanocomposites with improved mechanical properties. Materials \& Design. 2016;91:46-52.

116. Ust"un T, Eskizeybek V, Avci A. Enhanced fatigue performances of hybrid nanoreinforced filament wound carbon/epoxy composite pipes, Composite Structures. 2016;150:124-31.

117. Kleinschmidt AC, Almeida JH, Donato RK, et al. Functionalized-Carbon Nanotubes with Physisorbed lonic Liquid as Filler for Epoxy Nanocomposites. Journal of Nanoscience and Nanotechnology. 2016;16(9):9132-9140.

118. Randjbaran E, Zahari R, Majid DL, et al. Reasons of Adding Carbon Nanotubes into Composite Systems-Review Paper. "Mechanics and Mechanical Engineering". 2017;21(3):549-568

119. Akhilesh M, Santarao K, Babu MVS. "Thermal Conductivity of CNT-Wated Nanofluids: a Review." Mechanics and Mechanical Engineering. 2018; 22(1): 207220

120. Elias Randjbaran, Rizal Zahari, Dayang Laila Abang Haji Abdul Majid, et al. Literature Review Paper on Mechanical Properties of Types of Carbon Nanotubes. Journal of New Developments in Chemistry. 2018;1(4):27-43.

121. Mohammad S Al-Ajely, Kareema M Ziadan, Rafed M Al-Bader. Preparation and Characterization of Calcium Fluoride Nano Particles For Dental Applications. "International Journal of Research -Granthaalayah".2018; 6(1): 338-346.

122. Loris Rizzello, Nanotechnology Meets Immunotherapy: CAR-T Cells Technology and Beyond. Journal of Biomaterials.2018; 1(1):1-6.

123. Regina Guenka Palma-Dibb, Cristiane Savaris, Michelle Alexandra Chinelatti, Fabrício Augusto de Lima, Luciano Bachmann et al. Composite Photopolymerization: Temperature Increase According to Light Source and Dentin Thickness. Journal of Dentistry and Oral Implants. 2016;1(2):11-19. 